\title{
Business Objectives For Trade Shows Aimed At Final Consumers
}

\author{
Ainhoa Rodríguez-Oromendía, Ph.D., Spanish University of Distance Teaching (UNED), Spain \\ María Dolores Reina-Paz, Ph.D., Spanish University of Distance Teaching (UNED), Spain \\ Claudia Sevilla-Sevilla, BA, Spanish University of Distance Teaching (UNED), Spain
}

\begin{abstract}
An exhibitors' attendance at any trade show calls for designing and developing a preliminary plan, which must in turn be a part of the company's overall marketing plan, so that the decisions that are taken before, during, and after attending the trade show are in keeping with the company's sales and overall objectives. To achieve the desired sales and business performance, trade show objectives have to be set and defined as part of the strategic plan for attending the event, and this definition can have an influence on the final outcome the company achieves after the show. Taking this into account, and bearing in mind the particular case of trade shows aimed at final consumers, this paper describes a study based on cluster analysis aimed at grouping the different objectives that lead companies to attend trade shows and determine which of these objectives are most important for participating firms.
\end{abstract}

Keywords: Trade Show Objectives; Business Planning; Trade Show Marketing

\section{INTRODUCTION}

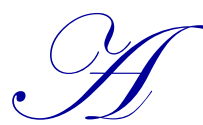

1987).

company's presence at a given trade show ought to involve developing a specific plan ahead of time, which must in turn be integrated within the company's overall marketing plan, so that the decisions that are made will be in keeping with the company's sales and overall objectives (Kerin and Cron,

According to Navarro (2001), objectives are "those specific, realistic, quantifiable goals that the exhibiting company hopes to achieve with its presence at the trade show." It is crucial to define objectives for each specific trade show and relate them directly to the company's overall marketing objectives (Puthod, 1983); setting these objectives is essential for the company's success at the trade show (Cavaugh, 1976; Bellizzi and Lipps, 1984).

Many companies still continue to make the serious mistake of participating in trade shows simply because their competitors do so or out of habit (Puthod, 1983; Tanner, 2002; Le Monnier, 2000; Navarro, 2001; Mottard, 2003), so they do not define specific, measurable objectives that can be assessed, and therefore they lack methods for evaluating the success or failure of their presence at the trade show (Blythe, 1996; Miller, 2003). In fact, Kitzing (1988) mentions a study in which apparently only $46 \%$ of exhibitors set objectives for participating in trade shows, and only half of that percentage set truly quantifiable objectives that were measured after the fact.

For a company to set the objectives to be fulfilled at the trade show, its management has to examine the following areas (Cavanaugh, 1976):

1. The company's aim at the trade show or the message it wishes to convey.

2. The target audience.

3. The advantages of exhibiting at local, regional, or national trade shows.

4. The global effectiveness that the trade show can provide for the company.

5. The competition's behavior at the trade show.

6. The budget and the forecast for the cost-to-sales ratio to be achieved. 
In addition, to correctly set the company's objectives for the trade show, it is important to bear in mind other aspects such as (Sashi and Perretty, 1992) the marketing plan objectives, the status of the product's lifecycle, the company's image in the marketplace, the influence of the competition on sales, and the quality of the booth staff.

Given their particular features, trade shows are appropriate for achieving many different objectives (Navarro, 2001; AUMA, 2006). In fact, certain authors have identified up to 100 different objectives (Siskind, 1997) that can be achieved by participating in a trade show.

There is no single way of classifying trade show objectives. Bonoma (1983) makes an interesting point by distinguishing objectives that are directly related to sales from non-sales objectives, aimed at both existing and potential customers (Table 2.2). Tanner (2002) and Gopalakrishna et al. (1995) suggest a similar classification, breaking objectives down into two categories, for promotion and sales. Navarro (2001), on the other hand, only considers three major objectives: sales, image, and promotion and research, because he includes developing new business within sales.

Many authors have performed research aimed at examining the most significant business objectives pursued in trade shows. Table 1 provides a summary of the most relevant studies and their conclusions:

Table 1. Summary of the results obtained by different studies of trade show objectives

\begin{tabular}{|c|c|}
\hline $\begin{array}{l}\text { Banting and Blenkhorn } \\
\text { (1974) }\end{array}$ & $\begin{array}{l}\text { - 1) Develop personal contacts, generate sales. } \\
\text { - 2) Introduce new products. } \\
\text { - 3) Have access to customers who would be difficult to reach otherwise. } \\
\text { - 4) Maintain the company's and the product's image. }\end{array}$ \\
\hline Kerin and Cron (1987) & $\begin{array}{l}\text { - 1) Try out new products. } \\
\text { - 2) Sell at the actual trade show. } \\
\text { - 3) Introduce new products. }\end{array}$ \\
\hline Munuera et al. (1993) & $\begin{array}{l}\text { - 1) Promote the company's image and improve its reputation. } \\
\text { - 2) Maintain the company's image and provide services to the company's existing customers. } \\
\text { - 3) Make new contacts with potential buyers. } \\
\text { - Introduce new lines or new products and measure subsequent reactions. }\end{array}$ \\
\hline Shipley et al. (1993) & $\begin{array}{l}\text { - 1) Meet new customers. } \\
\text { - 2) Promote existing products. } \\
\text {-3) Launch new products. }\end{array}$ \\
\hline Tanner and Chonko (1995) & $\begin{array}{l}\text { - 1) Secure sales. } \\
\text { - 2) Make contacts and explore the market. } \\
\text { - 3) Communication (promote the company's presence, enhance its profile, etc.) }\end{array}$ \\
\hline Blythe (2002) & $\begin{array}{l}\text { - 1) Contact new customers. } \\
\text { - 2) Launch new products. } \\
\text { - 3) Secure sales. }\end{array}$ \\
\hline $\begin{array}{l}\text { Gázquez and Jiménez } \\
\text { (2002) }\end{array}$ & $\begin{array}{l}\text { - 1) Make contact with potential customers. } \\
\text { - 2) Introduce new products. } \\
\text { - 3) Provide information about the company. }\end{array}$ \\
\hline
\end{tabular}

Source: Prepared by the authors 
Ultimately, there is no consensus as to what the objectives of a trade show really are; in fact, the number of objectives varies enormously, ranging from 100 according to Siskind (1997), 33 as suggested by AUMA (2006), down to eight posited by Puthod (1983). It seems fairly likely that the explanation for this enormous range lies in the fact that the objectives vary according to the industry and the type of trade show considered in each case.

\section{RESEARCH METHODOLOGY}

The study population includes the 333 businesses that exhibited at the EXPO-OCIO leisure trade show, which was solely aimed at final consumers. According to the information provided by the organizing committee, in addition to the number of exhibitors mentioned above, the trade show was attended by over 500,000 visitors - in other words, potential customers for the exhibitors-positioning the trade show as the most visited in Spain and as the foremost leisure trade show in Europe.

The field work was carried out in three stages: the first took place during the trade show by handing out a questionnaire to the sales manager for each exhibitor, along with a prepaid envelope so the survey could be returned by post. The purpose of the survey was explained to each one of the managers. The second stage took place one month after the trade show closed, and involved sending out questionnaires again by post with a letter of introduction and a prepaid envelope. Last of all, the third stage involved two other similar mailings; one two months after the trade show had closed and another one after the holiday period.

Once the field work was completed, a total of 198 questionnaires had been collected, 181 of which were valid, with a $54 \%$ sampling error. ${ }^{1}$ Table 2 shows the technical record of the survey.

Table 2. Technical record of the survey

\begin{tabular}{|l|l|}
\hline Scope & Exhibiting companies with direct physical presence at EXPO-OCIO 2009 \\
\hline Method For Collecting Information & $\begin{array}{l}\text { First contact: personal delivery of the questionnaire at the trade show } \\
\text { Other contacts: questionnaires sent by post }\end{array}$ \\
\hline Sample Census & 333 businesses \\
\hline Sample Size & 181 valid questionnaires \\
\hline Sampling Error & $+/-5.03 \%, 95,5 \%$ confidence level; $\mathrm{p}=\mathrm{q}=0,5$ \\
\hline Sampling Procedure & Discretionary, considering the nature of the study \\
\hline Field Work Dates & March-September 2009 \\
\hline
\end{tabular}

\section{RESULTS OF THE STUDY}

Given the large number of authors who have shown an interest in researching companies' objectives at trade shows (Banting and Blenkhorn, 1974; Puthod, 1983; Bonoma, 1983; Kerin and Cron, 1987; Munuera et al., 1993; Shipley et al., 1993; Shipley and Wong, 1993; Gopalakrishna et al., 1995; Tanner and Chonko, 1995; Siskind, 1997; Le Monnier, 2000; Navarro, 2001; Blithe, 2002; Tanner, 2002; Gázquez and Jiménez, 2002; Mesonero and Garmendia, 2004; Moreno et al., 2006; AUMA, 2006; Sicilia, 2008) we performed a cluster analysis to group the different objectives that drive companies to participate in trade shows.

The variable to use is: What are your objectives for participating in the trade show? Written multiple choice questions with eleven optional answers (Table 3):

\footnotetext{
${ }^{1}$ The response rate is high in relation to similar studies: O’hara (1993): N=202; 39.6\%. Tanner (1994): N=113; 75\%. Tanner and Chonko (1995): N=813; 20\%. Gopalakrishna and Lilien (1995): N=1135; 40\%. Hansen (1996): N=200; 44\%. Blithe (1999 y 2002): $\mathrm{N}=200 ; 52 \%$. Tanner (2002): $\mathrm{N}=3395 ; 23.2 \%$. Hansen (2004): N= 550; 18,4\% and Berné and García (2005): N=482; $30 \%$. In this case, the high response rate may be due to the fact that the questionnaire was handed out during the trade show to the sales managers from exhibiting companies, who were briefly told about the content of the survey; this made for a certain degree of commitment among respondents.
}

(C) 2012 The Clute Institute http://www.cluteinstitute.com/ 
Table 3. Objectives for participating in the trade show

\begin{tabular}{|l|}
\hline Introduce new products and developments \\
\hline Provide information about products and their uses \\
\hline Maintain existing business relationships \\
\hline Make new contacts with potential buyers \\
\hline Secure orders or generate sales \\
\hline Have access to customers who would otherwise be difficult to reach \\
\hline Attend because the competition does so \\
\hline Exchange experiences \\
\hline Get an overall sense of the state of the market \\
\hline Promote the company's image and improve its reputation \\
\hline Train new sales staff \\
\hline
\end{tabular}

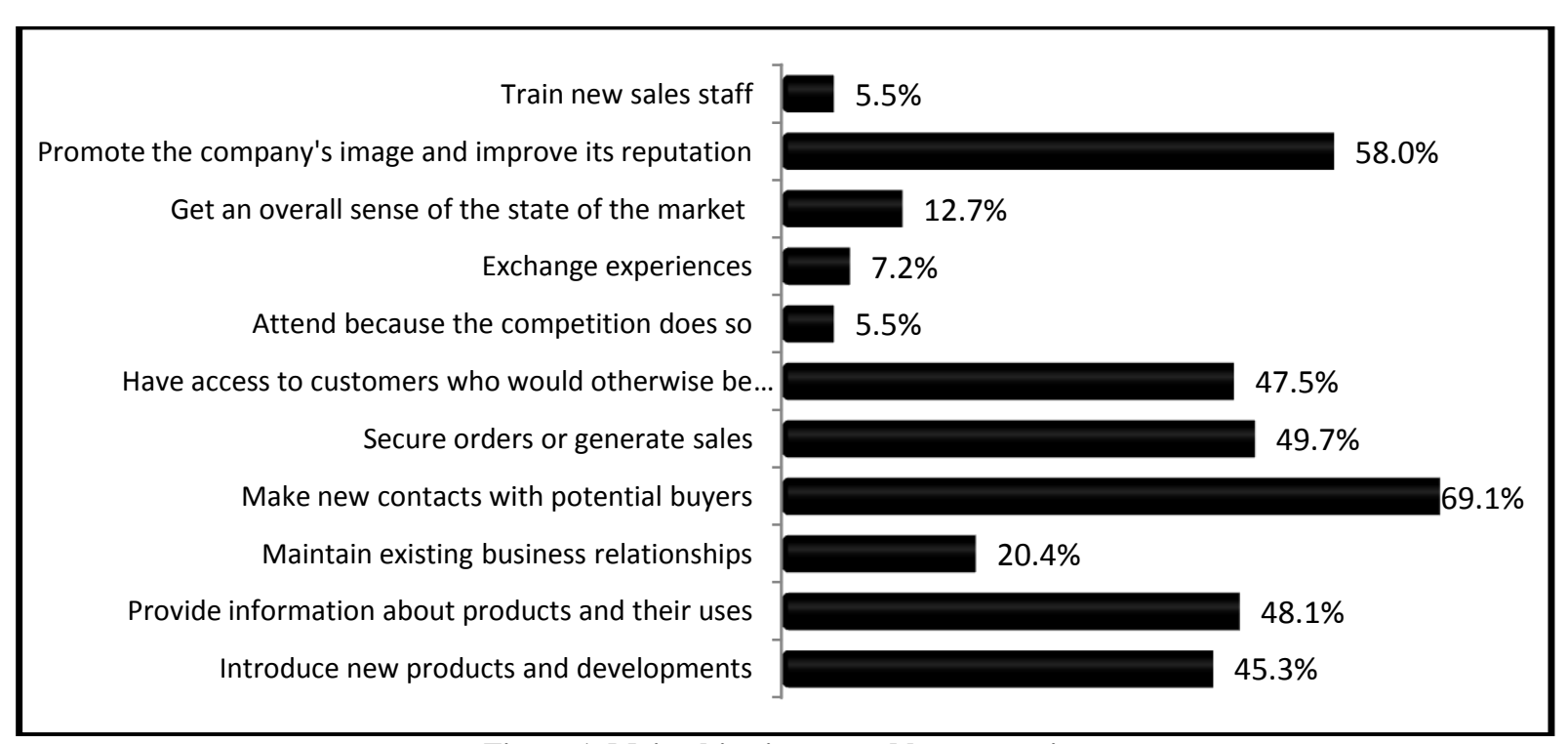

Figure 1. Main objectives stated by companies

According to the data we collected, the survey respondents' main goal for bringing their companies to EXPO-OCIO was to make new contacts with potential buyers, as stated by $69.1 \%$ of the surveyed businesses, although they also considered it essential to promote the company's image and improve its reputation (58\%). We should also highlight other important objectives for exhibitors, such as receiving orders and generating sales (49.7\%), providing information about products and their uses (48.1\%), having access to customers who would otherwise be difficult to reach $(47.5 \%)$ and introducing new products and/or developments $(45.3 \%)$. Clearly, since EXPO-OCIO is primarily aimed at final consumers and specialized retailers, sales objectives are more relevant than they would be in other kinds of trade shows, such as industrial shows where exhibitors tend to be more focused on non-sales objectives (Shipley et al., 1993).

We used cluster analysis to classify companies' objectives for attending trade shows. This enabled us to break down one of the categories into groups so that the objectives within each group were similar and the objectives in different groups were dissimilar. We began this study by running the Kolmogorov-Smirnov test to check whether the collected data followed a normal distribution. The Kolmogorov-Smirnov test for the sample is considered to be a goodness of fit test; essentially, it makes it possible to measure the degree of concordance between the distribution of a data set and a given theoretical distribution. Its purpose is to determine whether the data come from a population that has the given theoretical distribution, in other words, whether the data follow a normal distribution (Kazmier, 2006). 
Table 4. Normality test for the variables associated with the objectives set for the trade show

\begin{tabular}{|l|c|c|c|c|c|c|c|c|c|c|c|}
\hline Variable & OBJ1 & OBJ2 & OBJ3 & OBJ4 & OBJ5 & OBJ6 & OBJ7 & OBJ8 & OBJ9 & OBJ10 & OBJ11 \\
\hline $\begin{array}{l}\text { Kolmogorov- } \\
\text { Smirnov }\end{array}$ & 4.909 & 4.718 & 6.578 & 7.265 & 7.231 & 7.011 & 5.898 & 4.602 & 4.756 & 5.131 & 7.265 \\
\hline Significance & 0.000 & 0.000 & 0.000 & 0.000 & 0.000 & 0.000 & 0.000 & 0.000 & 0.000 & 0.000 & 0.000 \\
\hline
\end{tabular}

Table 4 shows that the variables follow a normal distribution, thus enabling us to proceed with subsequent tests.

As shown in Table 5 and in Figure 2, we can make out three groups of clusters: the first isolates the objective of introducing new products and developments; the second covers the most relevant objectives for exhibitors attending the trade show-objectives concerning sales, making new contacts, and promoting the company's image. The third cluster includes the objectives that are considered least valuable by exhibitors: the objectives aimed at relating the company with its environment and with existing customers are not viewed as particularly important.

Table 5. Clusters grouping the objectives set for the trade show

\begin{tabular}{|c|c|c|}
\hline Case & & Clusters \\
\hline (OBJ1) & Introduce new products and developments & 1 \\
\hline (OBJ2) & Provide information about products and their uses & 2 \\
\hline (OBJ3) & Maintain existing business relationships & 3 \\
\hline (OBJ4) & Make new contacts with potential buyers & 2 \\
\hline (OBJ5) & Secure orders or generate sales & 2 \\
\hline (OBJ6) & Have access to customers who would otherwise be difficult to reach & 2 \\
\hline (OBJ7) & Attend because the competition does so & 3 \\
\hline (OBJ8) & Exchange experiences & 3 \\
\hline (OBJ9) & Get an overall sense of the state of the market & 3 \\
\hline (OBJ10) & Promote the company's image and improve its reputation & 2 \\
\hline (OBJ11) & Train new sales staff & 3 \\
\hline
\end{tabular}

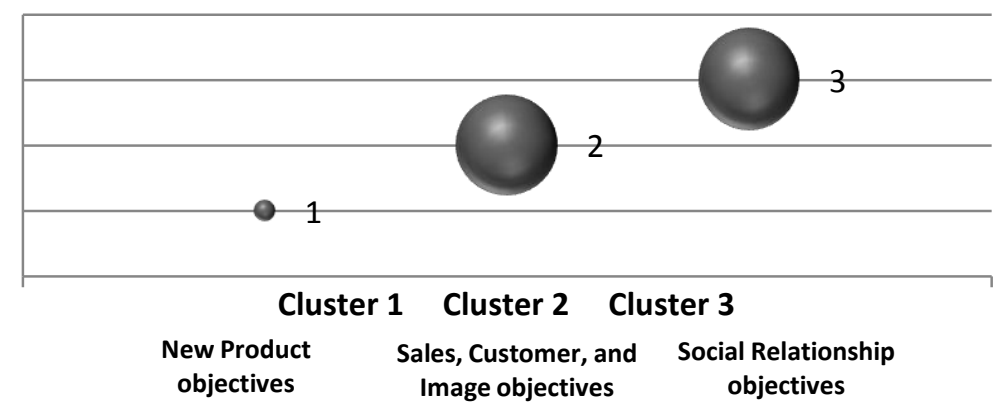

Figure 2. Size of trade show objective clusters

\section{CONCLUSIONS, BUSINESS IMPLICATIONS, AND LIMITATIONS}

The main conclusions of this study are the following:

When exhibitors are faced with the decision to participate in a trade show, they consider two main types of objectives: promoting their image, on the one hand, and sales, on the other. Those which focus on their image attend the trade show with the aim of providing information about their products, uses, and/or services, and of promoting their company's image, thus improving communication with their customers and their reputations.

Exhibitors whose main objective is focused on sales/customers consider it crucial to make new contacts with potential buyers in order to generate new sales during the trade show and thus reach new customers who would otherwise be difficult to reach. 
We also considered a third kind of objectives in our study, generally referred to as "social relationship objectives," which are scarcely taken into account by businesses. Attending a trade show because the competition does so, to exchange experiences, or to get an overall sense of the state of the market, are not reasons that companies value as relevant for participating in a trade show.

Therefore, the overall conclusion is that the main objectives that companies set for themselves when considering trade show attendance are "promotional and image objectives" and "sales/customer objectives."

Trade shows aimed at final consumers are viewed as marketing tools focused on the company's communication and promotion, and on selling products and services. Our results confirm the theoretical framework mentioned above.

To optimize the outcome of a trade show, companies must be capable of planning their activities effectively, making all the necessary efforts before, during, and after the event, since trade shows are highly efficient tools for boosting sales and for promoting a company's image and products.

Prior to the trade show, companies must clearly set the objectives they wish to achieve with their presence at the event, because those objectives can actually determine what the final outcome will be. This enables businesses to define the appropriate actions to be taken during and after the trade show. Bearing in mind that promoting the company's image is highly relevant in trade shows aimed at final consumers, companies wishing to gain a higher profile can benefit from this type of trade shows. However, for the general public to be aware of the event and hence for the company to achieve its goals, promotional efforts prior to the trade show are of critical importance.

Last but not least, I would like to point out several aspects that limit the scope of the results obtained in this study:

First of all, it is important to take into account the nature of the trade show we examined in our analysis, given that all the companies at EXPO-OCIO were leisure-related businesses that in many cases belong to highly diverse markets/products, which in turn have their own specialized trade shows. In fact, there is a trend towards greater specialization in the trade show industry (Navarro, 2001). However, many of these specialized events are not specifically aimed at final consumers, and therefore a multi-sector trade show may ultimately be the most appropriate option given the nature of this research.

Secondly, the study focused on the results obtained during one specific year-2009. It may be interesting to perform the same research over the course of several periods to be able to follow the development of the different variables we examined longitudinally. Likewise, we could consider the possibility of carrying this research over to other national or international events of this sort.

\section{AUTHOR INFORMATION}

Ainhoa Rodríguez-Oromendía, Ph.D. in Business from the Spanish University of Distance Teaching (UNED). Assistant Professor of Economics at the Business and Accounting Department. Faculty of Economic and Business Sciences. UNED (Spain). Research Interest: marketing, educational and tourism. Phone +34 606243177; Fax +34 91 3986374; E-mail: arodriguez@cee.uned.es

María Dolores Reina-Paz, Ph.D. in Business from the Spanish University of Distance Teaching (UNED). Assistant Professor of Economics at the Business and Accounting Department. Faculty of Economic and Business Sciences. UNED (Spain). Research Interest: marketing, educational and tourism. Phone +34 649946034; Fax +34 91 3987355; E-mail: $\underline{\text { mreina@ @ee.uned.es }}$

Claudia Sevilla-Sevilla, Undergraduate Degree in Geography \& History from the University of Barcelona. Associate Professor of Economics at the Business and Accounting Department. Faculty of Economic and Business Sciences. UNED (Spain). Research Interest: marketing, educational and tourism. Phone +34 675897190; Fax +34 91 3987355; E-mail: csevilla@cee.uned.es (Corresponding author) 


\section{REFERENCES}

1. Asociación Alemana del Sector de Ferias y Exposiciones (2006): Successful participation in trade fairs. Tips for exhibitors, available in: http://www.aumamessen.de/_pages/s/12_Download/download/tradefairpreparation/Successful_participation2006.PDF

2. Banting, P. M. and Blenkhorn, D. L. (1974): "The role of industrial trade shows", Industrial Marketing Management, 3 (5), 285-295.

3. Bellizzi, J. A. and Lipps, D. J. (1984): "Managerial guidelines for trade show effectiveness", Industrial Marketing Management, 13 (1), 49-52.

4. Berné, C. and García, M. (2005): "Origen y consecuencias de los resultados de la exposición en ferias profesionales", Congreso Internacional "La Tendencia del Marketing”, París.

5. Blythe, J. (1996): "The evaluation of non-selling activities at British trade exhibitions- an exploratory study", Marketing Intelligence \& Planning, 14 (5), 20-24.

6. Blythe, J. (1999): "Exhibitor commitment \& the evaluation of exhibition activities", International Journal of Advertising. 18 (1), 73-88.

7. Blythe, J. (2002): "Using trade fairs in key account management", Industrial Marketing Management, 31(7), 627-635.

8. Bonoma, T. V. (1983): "Get more out of your trade shows", Harvard Deusto Business Review, 15, 109118.

9. Cavanaugh, S. (1976): "Setting objectives and evaluating the effectiveness of trade show exhibit", Journal of Marketing, 40 (4), 100-103.

10. Gázquez, J. C. and Jiménez, J. F. (2002). "Las ferias comerciales en la estrategia de marketing. Motivaciones para la empresa expositora", Distribución y Consumo, 66, 76-83.

11. Gopalakrishna, S. and Lilien, G. L. (1995): "A three-stage model of industrial trade show performance", Marketing Science, 14 (1), 22-42.

12. Gopalakrishna, S., Lilien, G. L., Williams, J. D. and Sequeira, I. K. (1995): "Do trade shows pay off?”, Journal of Marketing, 59 (3), 75-83.

13. Hansen, K. (1996): "The dual motives of participants at international trade shows: an empirical investigation of exhibitors and visitors with selling motives", International Marketing Review, 13 (2), 3954.

14. Hansen, K. (2004): "Measuring performance at trade shows. Scale development and validation", Journal of Business Research, 57, 1-13.

15. Kazmier, L. J. (2006): Estadística aplicada a administración y economía. Mcgraw-Hill Interamericana, México.

16. Kerin, R. A. and Cron, W. L. (1987): “Assessing trade show functions and performance: an exploratory study", Journal of Marketing, 51 (3), 87-94.

17. Kitzing, F. (1988): Exhibiting by objectives: a guide to setting objectives for trade shows and realizing them. Trade Show Bureau, East Orleans.

18. Le Monnier, F. (2000): Marketing ferial. Ediciones Gestión 2000, Barcelona.

19. Mesonero, M. and Garmendia, F. (2004): "Comunicaciones integradas feriales o cómo planificar con éxito una feria industrial”, Revista de Dirección y Administración de Empresas, 11, 109-129.

20. Miller, S. (2003): Saque el máximo provecho de las ferias. Ediciones Urano, Barcelona.

21. Moreno, M. F., Reinares, E. M. and Saco, M. (2006): Planificación estratégica de las ferias comerciales. Dykinson, S.L., Madrid.

22. Mottard, E. (2003): “¿Cuánto es de rentable participar en una feria?”, Marketing y Ventas, 182, 44-47.

23. Munuera, J. L., Ruiz, S., Hernández, M. and Mas, F. (1993): "Las ferias comerciales como variable de marketing: análisis de los objetivos del expositor", Información Comercial Española, 718, 119-138.

24. Navarro, F. (2001): Estrategias de marketing ferial. ESIC Editorial, Madrid.

25. O'Hara, B. S. (1993): "Evaluating the effectiveness of trade shows: a personal selling perspective", The Journal of Personal Selling \& Sales Management, 13 (3), 67-77.

26. Puthod, L. (1983): “Análisis y objetivos de marketing en la participación en ferias", ESIC Market, 42, 3164.

27. Sashi, C. M. and Perretty, J. (1992): “Do Trade Shows Provide Value?”, Industrial Marketing Management, 21 (3), 249-255. 
28. Shipley, D. and Wong, K. S. (1993): “Exhibiting strategy and implementation”, International Journal of Advertising, 12 (2), 117-130.

29. Shipley, D., Egan, C. and Wong, K. S. (1993): "Dimensions of trade show exhibiting management", Journal of Marketing Management, 9, 55-63.

30. Siskind, B. (1997): The Power of Exhibit Marketing. Self-counsel Press, $4^{\mathrm{a}}$ ed. Ontario

31. Tanner, J. F. and Chonko, L. B. (1995): "Trade Show objectives, management, and staffing practices", Industrial Marketing Management, 24 (4), 257-264.

32. Tanner, J. F. (1994): "Trade shows mean bigger business", Baylor Business Review, 10 (spring), 16-18.

33. Tanner, J. F. (2002): "Levelling the playing field: factors influencing trade show success for small companies", Industrial Marketing Management, 31 (3), 229-239. 